Gut, 1975, 16, 727-731

\title{
The agglutinating antibody response in the duodenum in infants with enteropathic $E$. coli gastroenteritis
}

\author{
A. S. McNEISH, N. EVANS, H. GAZE, AND K. B. ROGERS \\ From the Institute of Child Health, University of Birmingham, and the Department of Microbiology, \\ Birmingham Children's Hospital
}

SUMMARY The agglutinating antibody responses in duodenal fluid and serum were measured serially in 15 infants with enteropathogenic $E$. coli gastroenteritis. Peak levels of duodenal agglutinins were recorded eight to 18 days after the onset of symptoms, and the titres fell within the next seven to 14 days. These antibodies were mainly of the IgA class but IgM antibodies were detected early in the response, especially in the youngest infants.

Serum antibody responses were detected in eight patients, but they correlated poorly with the titres of intestinal antibodies. No rise in serum antibodies was found in six infants. Further studies are required to determine whether these differences are host-derived or whether they reflect different pathogenic properties of the infecting organisms.

The importance of the secretory immune system as a defence mechanism has been well documented in man and animals (Tomasi, 1970). However, there have been few studies of the antibody response to Escherichia coli in the intestine of the human infant, especially during natural infections. Girard and Kalbermatten (1970) immunized orally a group of infants, using an antigenic preparation of 11 strains of $E$. coli, and found agglutinating antibodies in the duodenal fluid eight to $\mathbf{4 4}$ days later. Lodinova and Wagner (1970) and Lodinova, Jouja, and Wagner (1973) demonstrated specific coproantibodies in normal infants after colonization of the upper intestine by non-pathogenic $E$. coli 083 with an associated increase in both IgA and IgM in the stools.

We have extended our previous studies (McNeish and Gaze, 1974; McNeish, Gaze, and Evans, 1974) on acute enteropathogenic $E$. coli gastroenteritis in infants by measuring the agglutinating antibody response in the duodenal fluid and serum during natural infection. We have also tried to determine the immunoglobulin (Ig) class of the intestinal antibodies.

\section{Patients and Methods}

CLINICAL

Fifteen infants aged from 5 weeks to 15 months

Received for publication 9 June 1975. presented with acute diarrhoea and vomiting of one to five days' duration. $E$. coli of serotypic strains commonly associated with acute enteritis was isolated from the stools of each child during the acute phase of the illness and was not isolated after recovery. The $O$ serotypes were 026(1), 044(1), 055(1), 0112(1), 0114(6), 0119(2), 0126(1) and $0128(2)$. All infants were treated by fluid replacement and regrading of feeds. None had antibiotics, and clinical recovery was complete within three to 10 days in each case.

DUODENAL FLUID SPECIMENS

These were obtained by peroral intubation after a fast of from four to six hours. They were taken onto ice at $4^{\circ} \mathrm{C}$, centrifuged at $8000 \mathrm{~g}$ for 15 minutes to remove debris and bacteria, stored at $-20^{\circ} \mathrm{C}$, and studied within 48 hours. Duodenal fluid and serum were obtained from each infant as soon as the diagnosis was established and again four to 14 days later.

BACTERIAL AGGLUTINATION

In each case, the strain of $E$. coli to be used was obtained from the infant's faeces during the acute illness. A heat-killed suspension of the organism in phosphate-buffered saline ( $\mathrm{pH} \mathrm{7 \cdot 2)}$ was used at an optical density of 0.4 at $600 \mathrm{~nm}$. Doubling dilutions of duodenal fluid or serum were incubated in microtitre trays at $4^{\circ} \mathrm{C}$ for 16 hours before reading. Autoagglutination was considered to be excluded 
by negative saline controls and the consistent titres obtained with each suspension of organisms against commercial typing antisera (Wellcome).

IMMUNOGLOBULIN CLASS OF AGGLUTINATING ANTIBODIES (MODIFIED FROM REED AND WILLIAMS, 1971)

Monospecific sheep antihuman-IgG, -IgA and IgM antisera (generously supplied by Professor P. G. H. Gell) were absorbed with $E$. coli of the above serotypes to remove agglutinating anti$E$. coli antibodies. Absorptions were repeated until no agglutination could be obtained using neat serum. An amount of antiserum (usually 0.5-2 volumes) sufficient to precipitate specific immunoglobulin was added to $0.5-\mathrm{ml}$ volumes of duodenal fluid, incubated at $37^{\circ} \mathrm{C}$ for one hour and centrifuged at $14000 \mathrm{~g}$ for 45 minutes. The antisera were of known antigen-binding capacity; residual immunoglobulin in the supernatants was not measured. A reduction in bacterial agglutination titre of 2 dilutions or more in the supernatant was taken to indicate

the presence of agglutinating antibody of the appropriate Ig class. Absorbed non-immune sheep serum was used in control experiments.

\section{Results}

\section{AGGLUTINATING ANTIBODIES IN DUODENAL} FLUID

These are illustrated in figure 1. Antibodies were detected in all but one patient at the initial examination. Rising antibody titres were found until eight to 18 days after the onset of symptoms, and falling titres were recorded after 10 to 27 days.

\section{SERUM AGGLUTINATING ANTIBODIES}

These were measured in all but one infant and are illustrated in figure 2 . In six children, no agglutinin response was detected. Eight children had agglutinating antibodies in their sera, but the character of the response was much more varied compared with the duodenal response. The possible significance is discussed later.

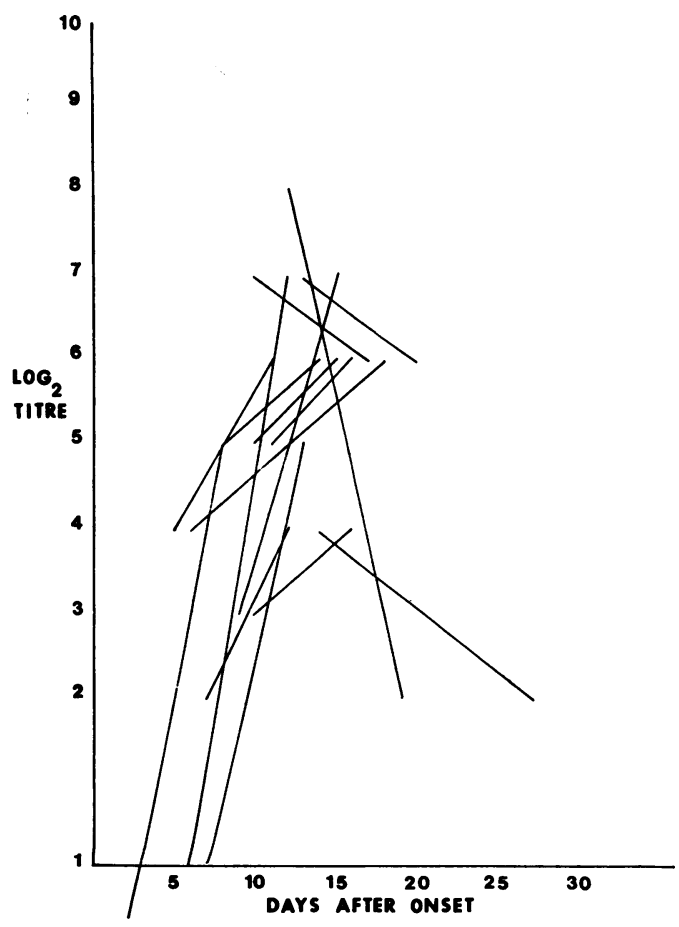

FIG 1

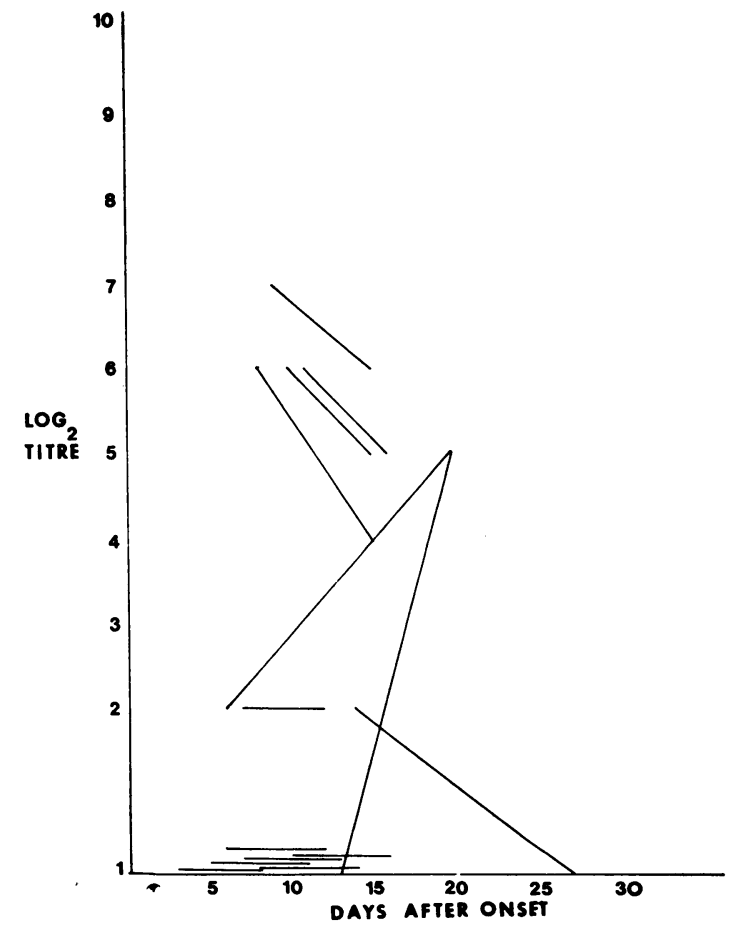

FIG 2

Fig 1 Agglutinating antibody titres in the duodenal fluid of each patient against a bacterial suspension of the infecting strain of E. coli.

Fig 2 Agglutinating anti-E. coli titres in the sera of 14 patients. 


\begin{tabular}{|c|c|c|c|c|c|c|c|}
\hline \multirow[t]{2}{*}{ Case } & \multirow[t]{2}{*}{ Age (months) } & \multirow[t]{2}{*}{ Day } & \multirow{2}{*}{$\begin{array}{l}\text { Log }_{2} \text { Titre } \\
\text { before } \\
\text { Absorption }\end{array}$} & \multicolumn{3}{|c|}{ Absorbed Titres ${ }^{1}$} & \multirow{2}{*}{$\begin{array}{l}\text { Antibody }{ }^{2} \\
\text { Class }\end{array}$} \\
\hline & & & & Anti $M$ & Anti $A$ & Anti $G$ & \\
\hline BS & 4 & $\begin{array}{l}10 \\
15\end{array}$ & $\begin{array}{l}5 \\
6\end{array}$ & $\begin{array}{l}3 \\
3\end{array}$ & $\begin{array}{l}3 \\
2\end{array}$ & $\begin{array}{l}3 \\
4\end{array}$ & $\begin{array}{l}\text { (M) (A) (G) } \\
\text { MA (G) }\end{array}$ \\
\hline $\mathbf{A L}$ & 5 & $\begin{array}{l}10 \\
16\end{array}$ & $\begin{array}{l}3 \\
4\end{array}$ & $\begin{array}{l}2 \\
4\end{array}$ & $\begin{array}{l}1 \\
1\end{array}$ & 3 & $\begin{array}{l}\mathbf{A} \\
\mathbf{A}\end{array}$ \\
\hline PS & 5 & $\begin{array}{l}10 \\
17\end{array}$ & $\begin{array}{l}7 \\
6\end{array}$ & $\begin{array}{l}3 \\
3\end{array}$ & $\begin{array}{l}5 \\
4\end{array}$ & 5 & $\begin{array}{l}\mathbf{M}(\mathrm{A})(\mathrm{G}) \\
\mathbf{M}(\mathrm{A})\end{array}$ \\
\hline WL & 5 & $\begin{array}{r}6 \\
12\end{array}$ & $\begin{array}{l}1 \\
7\end{array}$ & $\overline{5}$ & $\overline{4}$ & $\overline{-}$ & (M) $\mathrm{A}$ \\
\hline BC & 11 & $\begin{array}{l}14 \\
27\end{array}$ & $\begin{array}{l}4 \\
2\end{array}$ & $\frac{2}{-}$ & $\begin{array}{l}2 \\
0\end{array}$ & - & $\begin{array}{l}\text { (M) (A) } \\
\mathrm{A}\end{array}$ \\
\hline $\mathrm{JL}$ & 15 & $\begin{array}{r}7 \\
13\end{array}$ & $\begin{array}{l}1 \\
5\end{array}$ & $\begin{array}{l}\mathbf{0} \\
\mathbf{3}\end{array}$ & $\overline{2}$ & $\overline{5}$ & $\begin{array}{l}\text { (M) } \\
\text { (M) A }\end{array}$ \\
\hline
\end{tabular}

Table Immunoglobulin classes of duodenal agglutinating antibodies

${ }^{1} \log _{2}$ agglutination titres remaining after absorption of duodenal fluid with Ig-class-specific antisera.

${ }^{2}$ Brackets signify equivocal responses.

IG CLASS OF AGGLUTINATING ANTIBODIES IN DUODENAL FLUID

The available results on six patients are shown in the table. IgA antibodies were detected in all patients at some stage. IgM antibodies were detected in five and appeared to be the predominant antibodies in two. In two patients, IgG antibodies were also found.

\section{Discussion}

In 10 of the 15 cases, the episode of gastroenteritis occurred as part of an outbreak, either within a family, or in a closed ward. The same $E$. coli serotype was isolated fom each member of the group during the acute illness, and was not found after recovery. These observations, and the specific antibody responses discussed below, suggest strongly that the organisms were truly enteropathogenic, even though we did not attempt to measure enterotoxin production by these strains (Gorbach, 1970).

The antibody response to $E$. coli in the upper gut has been studied in animals and, less extensively, in human subjects. Porter, Noakes, and Allen (1970) instilled heat-killed $E$. coli into Thiry-Vella loops of jejunum in young pigs, and demonstrated agglutinating antibodies that appeared within three to four days, reached a peak around 10 days, and fell to low levels by 20 days. In mice infected with $E$. coli 0127, Kenny, Woleslagle, Gray, Michaels, and Pearson (1970) detected coproantibodies in adult animals that reached a peak around 30 days. No coproantibody response was found in infant mice. Lodinova et al $(1970,1973)$ allowed non-pathogenic $E$. coli 083 to colonize the upper intestine of normal human infants. Agglutinating coproantibodies were detected in the stools within one week, reached a peak at four weeks, and subsided slowly between 10 weeks and six months. This approximated closely to the time during which the bowel was colonized by E. coli 083. Girard and Kalbermatten (1970) immunized a group of infants orally with an extract of 11 strains of E. coli. Agglutinating antibody titres in the duodenal fluid were high by eight to 12 days and persisted for up to $\mathbf{4 4}$ days.

The pattern of response of duodenal agglutinins in the present study most closely resembles the data of Porter et al (1970). Variations in antigenic dose and persistence may explain the differences in other studies.

In many studies of intestinal antibodies, the role of $\operatorname{IgA}$ is rightly emphasized (Tomasi, 1970). However, antibodies of other immunoglobulin classes may be important, and differences may relate to species, age, type of antigen, or methods used to determine the immunoglobulin class of the antibodies.

In the young pig, Allen and Porter (1973) found that there were as many IgM as IgA cells in the lamina propria of the small intestine, although IgA was the predominant class of antibody produced in response to E. coli 0141 (Porter et al, 1970). In the unweaned calf, IgM is the major immunoglobulin class in the jejunal fluid (Porter, Noakes, and Allen, 1972). In rabbits infected with Trichinella, Crandall, Cebra, and Crandall (1967) found an increase in IgM cells in the gut lumina seven to 13 days after infection, with a later rise in IgG. The IgA cell count remained high throughout the infection. By indirect immunofluorescence most antibodies were of the IgG class.

Studies of human patients with enteric bacterial infections have given results that agree broadly. Northrup and Hossain (1970) investigated 10 adult patients with cholera and found that jejunal anti- 
bodies of $\operatorname{IgA}$ and IgM classes were produced during the course of the illness. IgG antibodies in serum and jejunum were high from the beginning of the illness and presumably were the result of previous infection. IgM and later IgA antibodies were detected in the sera. Reed and Williams (1971) studied 14 adults with shigellosis. IgA was the major immunoglobulin in stool fluid. Determination of the immunoglobulin class of the antibodies (using a technique similar to that used in the present study) indicated $\operatorname{IgA}$ antibodies in two, IgM antibodies in three, IgM and IgA antibodies in two, IgA and IgG antibodies in one, and all three classes of immunoglobulin antibodies in one patient. Girard and Kalbermatten (1970) measured the production of antibodies in the duodenal fluid of 12 infants eight to 44 days after oral immunization with extracts of 11 strains of $E$. coli. Agglutinating antibody titres had a geometric mean of $17 \cdot 2$, with virtually zero values for controls. The antibodies were of IgM class at eight to 12 days, and were $\operatorname{IgA}( \pm \operatorname{IgM})$ at 22 to 32 days. No serum antibodies were detected.

Lodinova et al (1973) observed the development of faecal immunoglobulins and coproantibodies in groups of infants after oral colonization with $E$. coli 083. IgA and to a lesser extent IgM were found in the stools. Haemagglutination titres rose over the first four weeks to approximately $1: 32$ and persisted at this level for 16 weeks, during which time $E$. coli 083 remained dominant in the bowel flora. Antibody titres in the stools appeared sooner than in serum.

Our observations confirm that IgA-coproantibodies are found at the height of the response in infants but suggest that IgM antibodies may be important perhaps at an earlier stage. In our method of detecting the Ig class of the antibodies by precipitation with specific anti-Ig antisera, we have chosen to consider a reduction of 2 dilutions in agglutination titre to indicate the presence of class-specific antibodies. This may be of borderline significance in some cases. On the other hand, it is unlikely that our precipitation technique removes the total Ig from the intestinal fluid or serum, so that the contribution of each Ig class may be underestimated. Bacterial agglutination techniques favour the detection of IgM and IgA antibodies rather than those of IgG class, so that we may have missed a significant IgG response.

The source of these intestinal antibodies is not known. The lack of correlation between serum and intestinal titres strongly suggests that the coproantibodies are not the result of leakage from the serum into the gut lumen. A lack of correlation between serum and gut antibodies has also been noted in the human studies of Girard and Kalbermatten (1970) and Lodinova et al $(1970,1973)$, in the studies of $E$. coli 0127 in mice by Kenny, Weinert, and Gray (1974), and in E. coli 0149 infections in the pig studied by Porter, Kenworthy, Holme, and Horsfield (1973). In contrast Fubara and Freter (1972) suggested that, in rabbits, a large proportion of intestinal antibodies were serum-derived.

No rise in serum antibodies was detected in six of our 15 patients. The explanation is not known. It may represent a difference in host response, or it may be the result of different properties of the infecting organism. Dupont, Formal, Hornick, Snyder, Libonati, Sheahan, LaBrec, and Kalas (1971) showed that some strains of enteropathogenic $E$. coli can penetrate mucosal barriers, in contrast to the majority of $E$. coli that remain within the gut lumen. The relationship of these properties to antibody responses requires further study.

We have measured agglutinating antibodies only. The protective effects of coproantibodies against $E$. coli are likely to be much more complex, involving antibacterial, antitoxic and anti-adherence properties (Smith and Linggood,1971). Nevertheless it is of interest that we have recently studied three children with severe and protracted $E$. coli gastroenteritis in whom the coproantibody response was low. (Details will be published elsewhere.) Agglutinating coproantibodies may be important in the defence against enteropathogenic $E$. coli in human infants.

We are grateful to Professor Charlotte Anderson for her interest and encouragement, and to Professor P. G. H. Gell for laboratory facilities. Our consultant colleagues at Birmingham Children's Hospital and East Birmingham Hospital kindly allowed us to study patients in their care. We thank Dr F. Bridgewater for help with bacterial identification, and Jean Fleming and Philip Turner for excellent technical help.

The work was supported by a grant to ASMcN and KBR from the Medical Research Council.

Requests for reprints to $\mathrm{ASMcN}$, Institute of Child Health, Francis Road, Birmingham B16 8ET.

\section{References}

Allen, W. D., and Porter, P. (1973). The relative distribution of IgM and IgA in the intestinal mucosa and lymphoid tissues of the young unweaned pig and their significance in ontogenesis of secretory immunity. Immunology, 24, 493-501.

Crandall, R. B., Cebra, J. J., and Crandall, C. A. (1967). The relative proportions of IgG-, IgA- and IgM-containing cells in rabbit tissues during experimental trichinosis. Immunology, 12, 147 . 158.

Dupont, H. L., Formal, S. B., Hornick, R. B., Snyder, M. J., Libonati, J. P., Sheahan, D. G., LaBrec, E. H., and Kalas, J. P. (1971) Pathogenesis of Escherichia coli diarrhea. New Engl. J. Med., 285, $1-9$.

Fubara, E S., and Freter, R. (1972). Availability of locally synthesızed and systemic antibodies in the intestine. Infect. Immun., 6, 965-981. 
Girard, J. P., and de Kalbermatten, A. (1970). Antibody activity in human duodenal fluid. Europ. J. clin. Invest., 1, 188-195.

Gorbach, S. L. (1970). Acute diarrhoea - 'toxin' disease? New Engl. J. Med., 283, 44-45.

Kenny, J. F., Woleslagle, D. L., Gray, J. A., Michaels, R. H., and Pearson, M. A. (1970). Enteric infection with Escherichia coli 0127 in the mouse. I. Characteristics of infection and systemis and local immune responses in mice of different ages. J. infect. Dis., 121, 528-540.

Kenny, J. F., Weinert, D. W., and Gray, J. A. (1974). Enteric infection with Escherichia coli 0127 in the mouse. II. Failure of specific immunity to alter intestinal colonisation of infants and adults. J. infect. Dis., 129 10-20.

Lodinova, R., and Wagner, V. (1970). Development of faecal immunoglobulins and coproantibodies in infants after artificial oral colonisation with E. coli 083. Experentia (Basel), 26, 188.

Lodinova, R., Jouja, V., and Wagner, V. (1973). Serum immunoglobulins and coproantibody formation in infants after artificial intestinal colonization with Escherichia coli 083 and oral lysosyme administration. Pediat. Res., 7, 659-669.

McNeish, A. S., and Gaze, H. (1974). The intestinal antibody response in infants with enteropathic E. coli gastroenteritis. (Abstr.) Acta. paediat. scand., 63, 663 .

McNeish, A. S., Gaze, H., and Evans, N. (1974). Agglutinating antibodies in the duodenal secretions of infants with enteropathic E. coli gastroenteritis. (Abstr.) Gut, 15, 834.

Northrup, R. S., and Hossain, S. A. (1970). Immunoglobulins and antibody activity in the intestine and serum in cholera. II. Measurement of antibody activity in jejunal aspirates and sera of cholera patients by radioimmunodiffusion. J. infect. Dis., 121, Suppl. 142-146.

Porter, P., Noakes, D. E., and Allen, W. D. (1970). Intestinal secretion of immunoglobulins and antibodies to Escherichia coli in the pig. Immunology, 18, 909-920.

Porter, P., Noakes, D. E., and Allen, W. D. (1972). Intestinal secretion of immunoglobulins in the preruminant calf. Immunology, 23, 299-312.

Porter, P., Kenworthy, R., Holme, D. W., and Horsfield, S. (1973). Escherichia coli antigens as dietary additives for oral immunisation of pigs: trials with pig creep feeds. Vet. Rec., 92, 630636.

Reed, W. P., and Williams, R. C. (1971). Intestinal immunoglobulins in shigellosis. Gastroenterology, 61, 35-45.

Smith, H. W., and Linggood, M. A. (1971). The effect of antisera in protecting pigs against experimental Escherichia coli diarrhoea and oedema disease. J. med. Microbiol., 4, 487-493.

Tomasi, T. B. (1970). Structure and function of mucosal antibodies. Ann. Rev. Med., 21, 281-298. 